\begin{tabular}{ll}
\hline CURRENT & ISSN: 0973-4929, Vol. 13, No. (2) 2018, Pg. 232-241 \\
WORLD & Current World Environment
\end{tabular}

ENVIRONMENT Journal Website: www.cwejournal.org

\title{
Quantification and Composition of Solid waste Abundance on the Beaches of Karachi, Pakistan
}

\author{
OMM-E-HANY ${ }^{1}$, ASIA NEELAM ${ }^{1 *}$, FAYYAZ SALIH HUSSAIN ${ }^{2}$ \\ AAMIR ALAMGIR ${ }^{1}$ and SUNILA KANWAL ${ }^{1}$
}

${ }^{1}$ Institute of Environmental Studies, University of Karachi, Pakistan.

${ }^{2}$ National center of Excellence in Analytical Chemistry, University of Sindh, Jamshoro, Pakistan

\begin{abstract}
The problem of the marine pollutants accumulation and its serious consequence leads dangerous to marine life, possess risk to human health, disturb marine activities like fishing and other uses of sea water, indulged scientists around the whole world with no easy solution in the coming years. The situation is now getting worst with the plastic which contribute $80 \%$ of the total solid waste in all the beaches provides ideal environment for the opportunistic microorganism to grow and establish a novel means of spatial and temporal transport for microorganisms diagonally coastal areas. This work contained baseline study of abundance, composition and nature of the solid waste on the beaches of Karachi, Pakistan which was investigated by quadrates method along the shoreline. During the study plastic litter identified $80 \%$ in proportion among all the beaches debris. The abundance of debris by weight was higher in Clifton followed by sandspit and Ghizri creek respectively. Thermocol / Styrofoam recoded as the second largest contributor of marine debris. The major contributing factor of debris abundance are beach visitors such as tourism, recreation activities, land based sources including waste generated from creeks provide a major input of pollution in beaches.
\end{abstract}

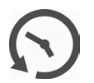

Article History

Received: 06 May 2018 Accepted: 10 August 2018

\section{Keywords}

Karachi, Microorganism, Pollution,

Plastic,

Thermocol.

\section{Introduction}

Marine pollution is one of the most priority issues facing by the whole world. It damages the ecosystem and habitat of many marine organism of coastal environment. To rectify this problem, number of monitoring programs have been initiated ${ }^{1-2}$. Solid waste generated form anthropogenic activates along with coast line have a unique characteristic higher generation densities. The waste originated from different sources have tendency to transport through current, wind and wave action reported waste transfer from far-flung continents and remote island through tidal and wave movement. 
Solid waste generated in coastal areas, which is usually found along the shoreline, has high proportionality of plastic relate debris are slowly degradable ${ }^{3-5}$. Sheavly (2005) reported $70-80 \%$ of marine pollution associated with plastic waste ${ }^{6}$ Accumulation of this debris on beaches reduces the aesthetic view, causing the harm to wildlife. It is estimated over 6000 species are effected by plastic litter to update $e^{7-8}$ marine organisms ingested the macro and micro plastic as the food particles, the effects of these particles include the internal and/or external abrasions and ulcers; and blockages of the digestive tract, which resulted in satiation, starvation and physical deterioration ${ }^{9}$. According to the U.S Marine Mammal Commission, 136 marine species have been reported in entanglement incidents, including six species of sea turtles, 51 species of seabird, and 32 species of marine mammals ${ }^{10}$.

There are few studies describing the quantity and quality of solid waste in the water column on beaches, mostly solid waste is associated with shoreline are highly reported and monitoring worldwide ${ }^{11}$. However plastic i.e Synthetic polymers (PET, PP PE, LDPE, HDPE) constitute the major part of floating marine debris. The major used plastic type polyethylene (PE) and polypropylene (PP) have lower densities than seawater, they float easily in water bodies due to their density or ultimately sink because their density changed due to biofouling and leaching of additives. Therefore Deep-sea surveys showed 50\% of plastic litter objects sink to the seafloor ${ }^{12}$. The geographic distribution of debris on the ocean base is characteristically subjective by geomorphology, hydrodynamics, and human factors ${ }^{5,15}$. Presence of large amount of plastics has been reported in seabed of all seas and oceans ${ }^{14-16}$ but less reported in remote areas such as Antarctica, particularly in deep waters ${ }^{16}$. Pakistan is considered adeveloping country, blessed with a long coastal area which is under threat due to variety of pollutants. the industrial wastewater discharge into sea is considered the top environmental issue in Karachi, now solid waste generation on coastal areas and its impact become a considerable issue. Only a few studies have been done to estimate the costal debris ${ }^{17-18}$. The present study is the comprehensive attempt to figure out the complete picture of Karachi coast in the terms of solid waste composition and distribution.

\section{Method}

Karachi is situated between $24^{\circ} 45^{\prime} \mathrm{N}$ to $25^{\circ} 37^{\prime} \mathrm{N}$ and $66^{\circ} 42^{\prime} \mathrm{E}$ to $67^{\circ} 34 \mathrm{E}$ along $27 \mathrm{~km}$ shoreline of the Arabian Sea. The coast of Karachi starts from Hub River out fall in the Arabian Sea and the open sea coastline of Karachi ends at Korangi creek. The coastline of Karachi which consists of Sandy, rocky and recreational beaches (Clifton, Paradise, Sandpit, Hawskbay, Turtle beach, Sonorah beach and French beach).

The study was conducted on four main beaches and 2 creeks of the Karachi coast (figure 1). Among the solid waste Composition, this study also focused on classification of three types of plastic including large microplastic, ( 1 to $<6 \mathrm{~mm}$ ), mesoplastic ( 6 to $<25 \mathrm{~mm}$ ) and macro plastic ( $\geq 25 \mathrm{~mm}$ ) respectively. The particles size less than $1 \mathrm{~mm}$ cannot be identified without microscope, this study is targeted on the mention sized ranged for the microplastic.

For the estimation of solid waste and quantification of plastic particles $10 \times 10 \mathrm{~m}$ large quadrates were selected along the shoreline and collected all the solid waste in the range of quadrate and sieve out the micro and macro plastic. Debris on the sieve was stored in the zipper bags separately and sent to the laboratory. Natural debris such as dead leaves, fish bones, seaweeds were excluded during sorting and categorizing of solid waste. Each type of item was counted and recorded against each class. The abundance and relative proportionality of solid waste on three sampled beach sites were compared by calculating total amount of waste generate on 25 quadrates.

\section{Result and Discussion}

The coastal area is one of the most productive areas which provides fish and other seafood but also helps trade in immense volume. Debris in the aquatic environment increased threats to the marine environment and possess great challenge for control and remediation. Contribution of human activity mostly beach visitors and recreation activity is a primary source of debris on the coastal line. This research work presents the baseline information on coastal beaches debris at Karachi, Pakistan. Nature has endowed Pakistan with some of the finest beach areas in the region but the expansion 
of industrialization degrades the coastal areas and natural marine environment. The data analysis of waste indicates the majority of items related to food packings, bottles, bags and cups. Plastic accounted for $88 \%$ among the total calculated debris on designated site. This plastic debris can be found floating in all the world's oceans and everywhere. The seabed especially near coastal regions are badly contaminated, with plastic bags. The debris which was less common on the beaches was fishing net as they are highly disperse to the wave current. Thermocol/ Styrofoam accounted the second largest pollutant in coastal area. It has a significant impact on marine environment as they are light weighted, easily float and break down into small pieces and accumulate in the marine habitat as micro and macro particles. In Koran, Chile and Japan Styrofoam reported as a serious pollution ${ }^{18-20,32}$.

\section{Sampling site Map}

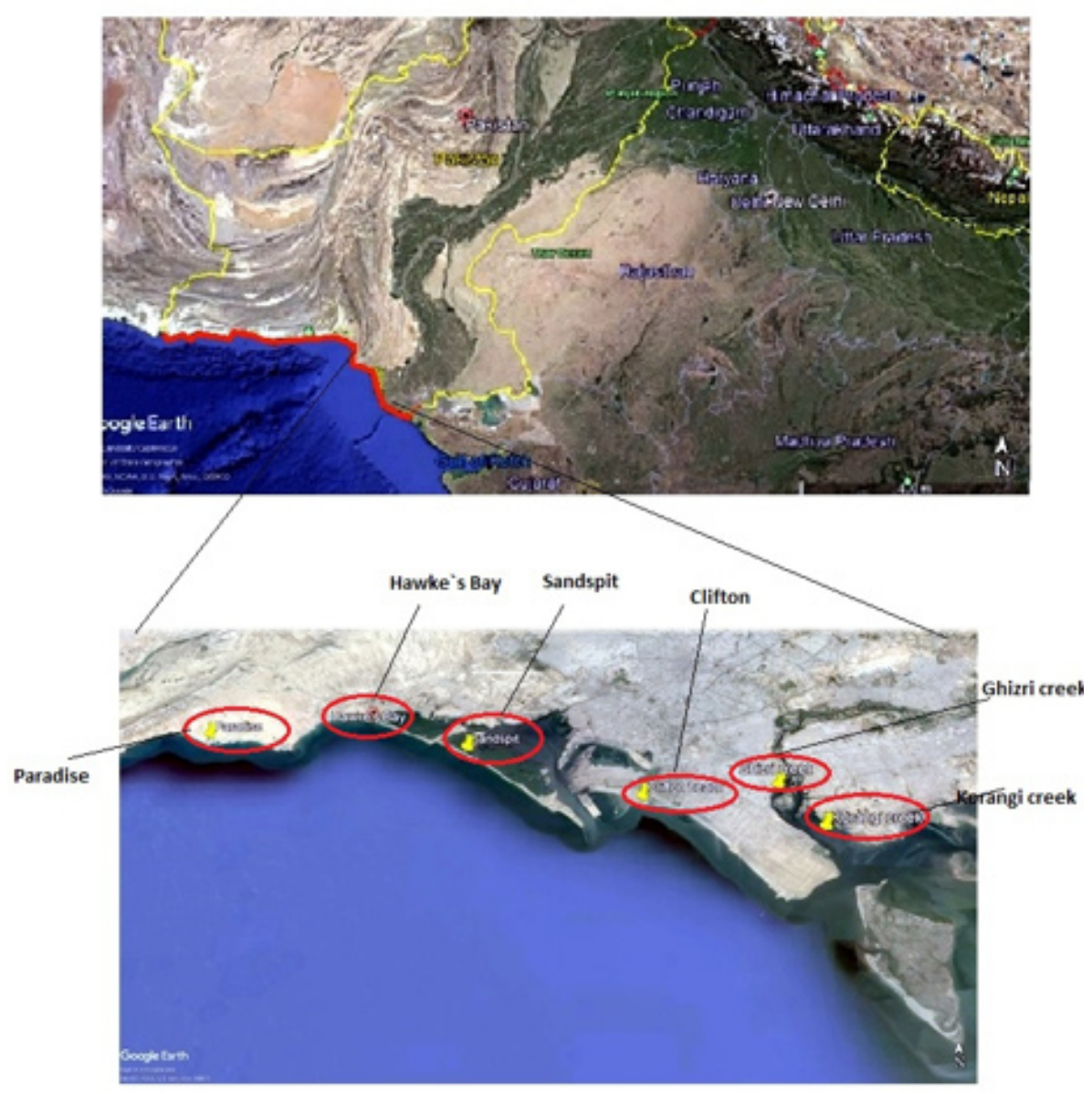

Fig. 1: Shows the map of Pakistan along its total coastal areas as the second zooming picture represent athe located sampling sites at beach of Karachi, Pakistan

As per the current survey the behavior of visitor i.e. accidently or intentionally litter the beach is an important contributor of marine pollution.Among all the beaches, most dominant item in terms of weight were plastic, almost all the beaches of Karachi were polluted from plastic. Following the global tendency ${ }^{21,22}$ this non-degradable, long durable and inexpensive polymer makes up the highest 
percentage of total items recorded in the area (Fig. 4 to Fig. 9). Only one study ${ }^{17}$ have been conducted in the past covers the all beaches of Karachi. According to that study one most common item were recorded was plastic, and Paradise beach was characterized as the most pollutant beach. Our result showed higher amount of plastic as compared to the Qari $\mathrm{R}^{17}$ study which means there was an increased amount of litter on the coast of Karachi within two or three years. Zalasiexicz ${ }^{23}$. it has been estimated that amount of plastic in the sedimentary deposit seems likely to grow several-folds over the next few centuries. Therefore an immediate action is very necessary to clean it. This debris somehow affects the health of beach visitors causing aesthetic problem and fatal consequences for marine biota ${ }^{25-27}$.
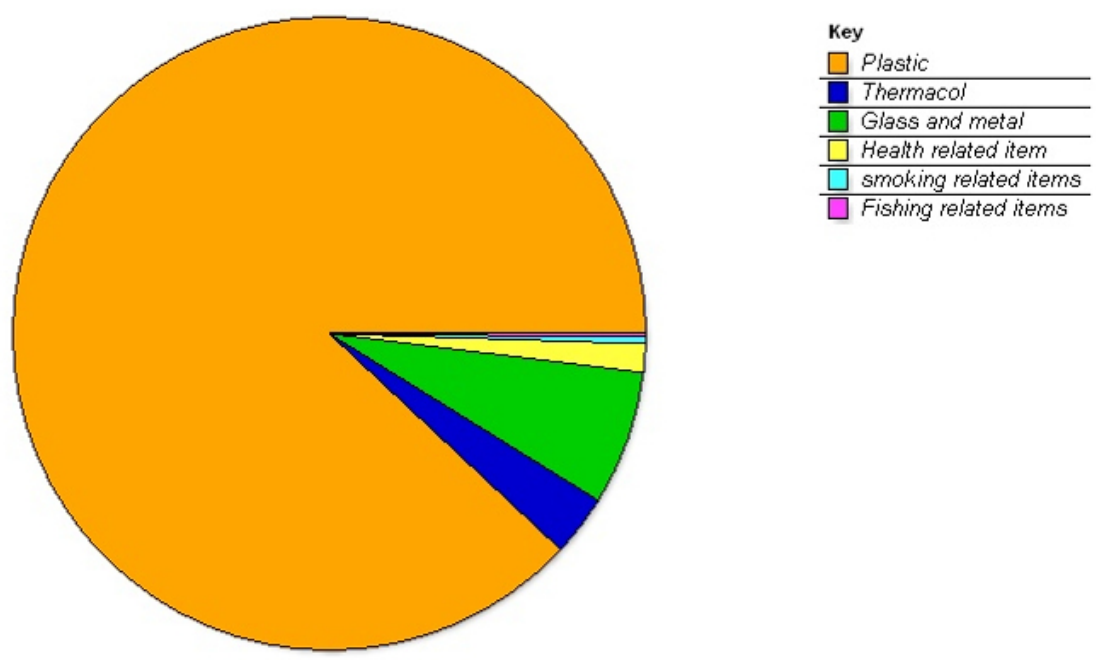

Fig. 2: Proportionality of marine debris recorded in coastal beaches of Karachi, Pakistan

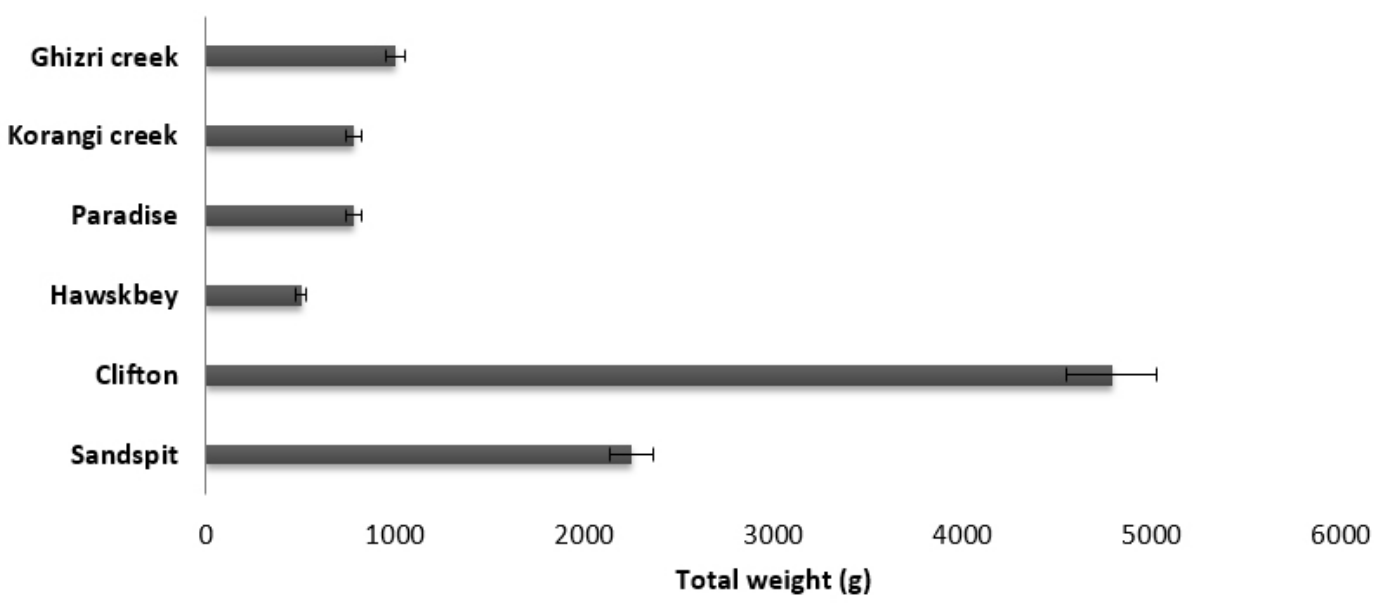

Fig. 3: Total plastic debris collected (a) Sandspit (b) Clifton (c) Hawsbey (d) Paradise (e) Korangi creek (f) Ghizri creek

The comparison of all beaches revealed that Clifton beach had greater qualities of debris than other sampling sites (Fig 3). The second large debris was glass and metals, as this side contain number of food canteens for facilitates the visitors. Mostly they are the non-degradable and devastated pollutants effect the marine life along the coast and off-shore. Apart from this, water quality of Clifton beach is continuously 
degraded by industrial and domestic discharges 27,28 as it receiving wastewater of two ephemeral rivers, namely Lyari and Malir River carrying the floating debris along with wastewater of city. Shaheen et al., reported that costal water of Karachi polluted with the pathogenic bacteria Escherichia coli, Streptococuss anginosus, Salmonella typhimurium, Psuedomonas aeroginosa, Staphylococuss aureus and Bacillus subtilis indicated the unhygienic coastal environmental.

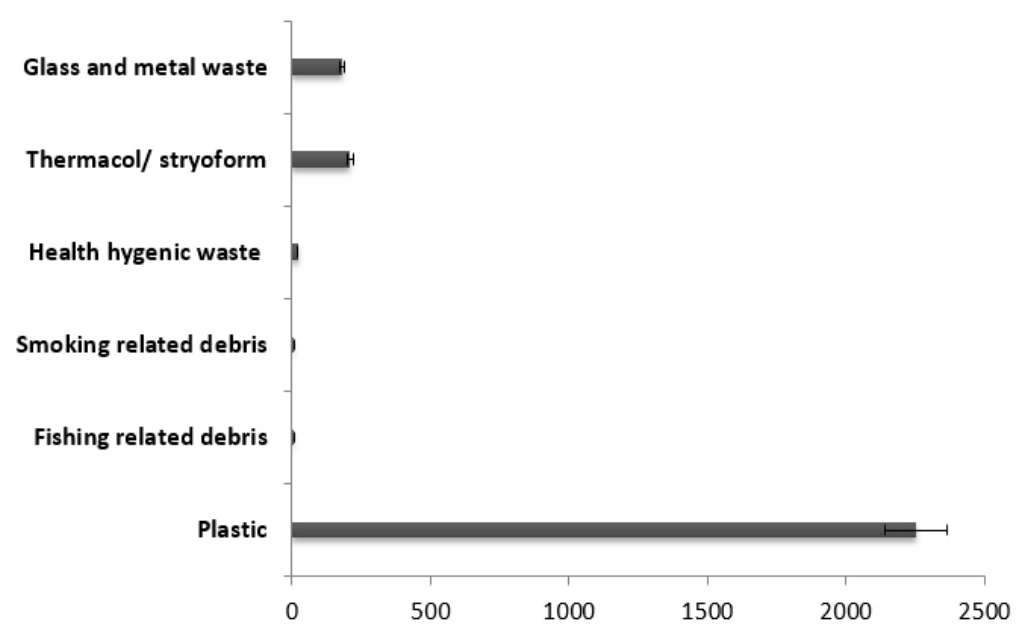

Fig. 4: Composition of solid waste on the Sandspit beach

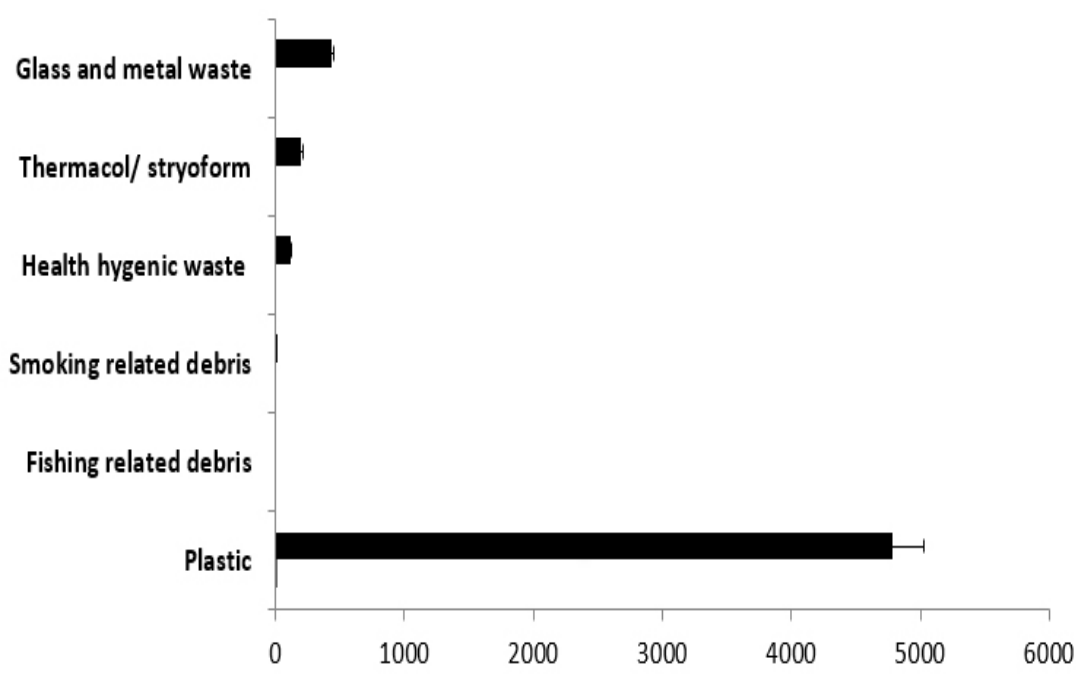

Fig. 5: Composition of solid waste on the Clifton beach

Sandspit and Hawksbay beaches are two of the eleven internationally most significant nesting beaches. Thousands of Green Sea Turtles (Chelonia mydas) nest on Sandspit and Hawksbay beaches every year. Our results indicated higher number of
Plastic pollution in sandspit followed by Paradise and Hawks' bay (Fig 3,4 and 7). These sites are far away from the city as compared to Clifton and mostly cover with the huts therefore these are less polluted as compare to Clifton beach. However metal and glass 
waste higher on those sites as visitors are usually love these sites for night stay bring glass bottles and metal items for their entertainment activity and ultimate dispose of on the beaches.

Creek areas of Karachi coast appear to be as polluted as the coastal beaches. The total waste collected from the creeks i.e. Korangi and Ghizri are $2365.5 \mathrm{~g}$ and $1039.8 \mathrm{~g}$ respectively.Thermocol/ Styrofoam are absent in these area (Table 1).Korangi and Ghizri creek are the worst affected creek, where the discharge from industries area, Landi, Korangi and Pakistan steel mill are straight away discharge their wastewater into the sea ${ }^{29,20}$. In the terms of water quality, Korangi creek was found to be most polluted with coliform and other pathogenic bacteria. Shaheen et al., 2016 reported the prevalence of Vibrio alginolyticus along with Vibrio parahaemolyticus in Ghizri creek, followed by other commonly reported bacteria. According to the Latest study of Amarl et al., 2015 plastic becoming an important media of transporting the microorganism across the coastal environment. The nature and structure of plastic facilitates the growth of unique microbial communities, many scientist called it "Plastisphere".as its act as a reservoir of harmful algal bloom species, faecal indicator organisms and pathogenic bacteria ${ }^{30,31}$.

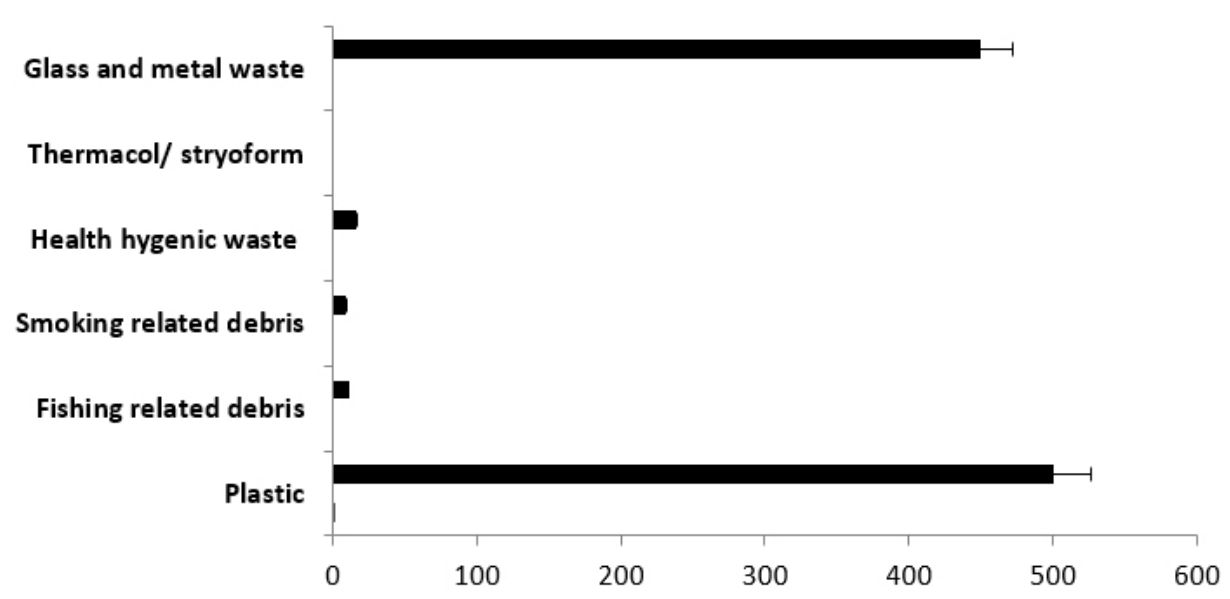

Fig. 6: Composition of solid waste on the Hawskbey beach

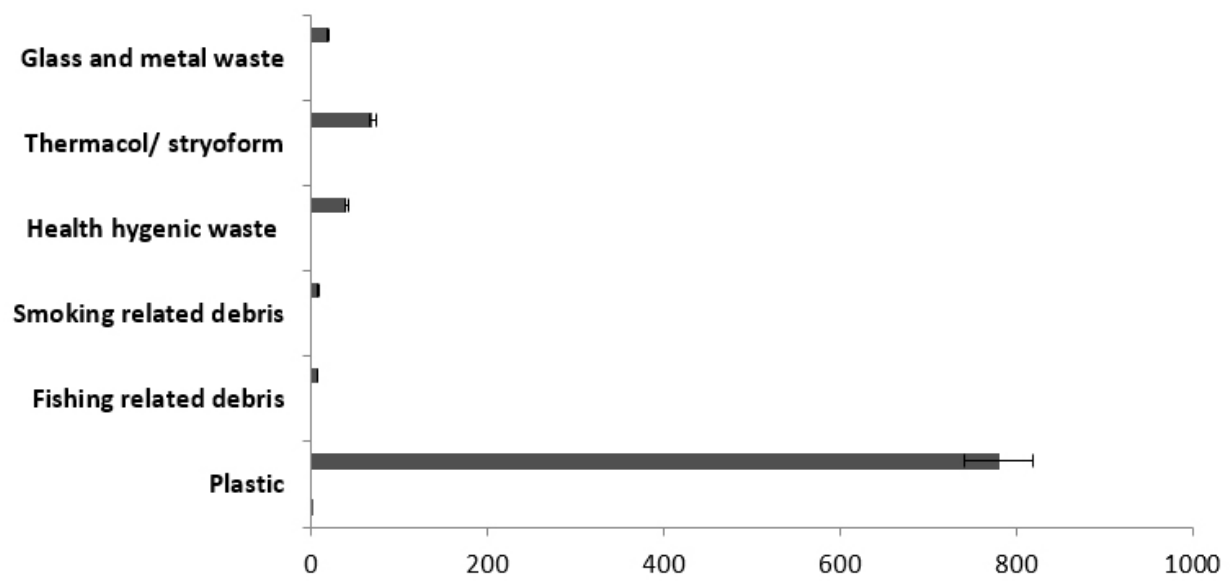

Fig. 7: Composition of solid waste on the Paradise beach 


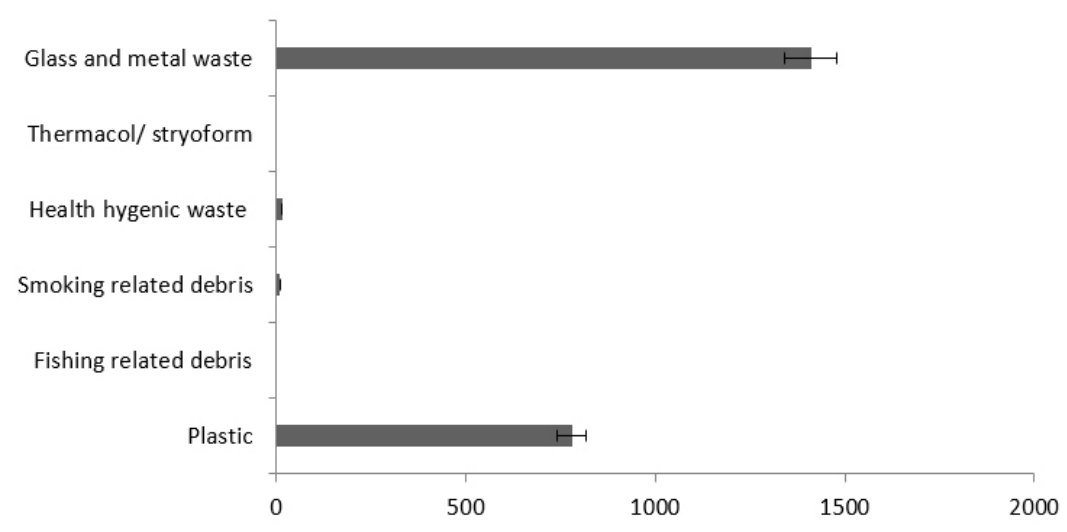

Fig. 8: Composition of solid waste on the Korangi creek

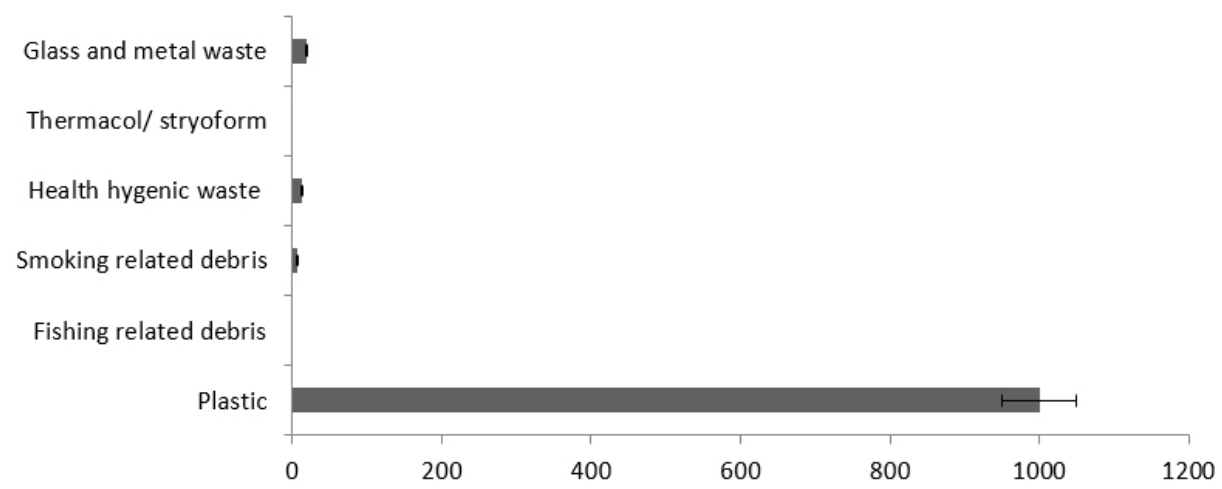

Fig. 9: Composition of solid waste on the Ghizri creek

Table 1: Description of solid waste collected at different sites of Karachi coast

\begin{tabular}{lllll}
\hline $\begin{array}{c}\text { S. } \\
\text { No. }\end{array}$ & Category of waste & Sample beach & $\begin{array}{l}\text { Total Weight } \\
\mathbf{( g )}\end{array}$ & Item Description \\
\hline 1 & Fishing/aquaculture/ & Hawskbay & 10.8 & ropes, cords, \\
& Shipping related debris & Sandspit & 8.2 & \\
& & Paradise & 7.6 & Cigarette lighters/ \\
& Smoking related debris & Hawskbay & 9.5 & Butts, Match box \\
& & Sandspit & 7.3 & and Filters \\
& Paradise & 8.6 & \\
& Clifton & 7.6 & Slippers, tooth \\
& & Koragi creek & 10.5 & paste, soles, \\
& & Ghizri Creek & 7.0 & tablets leaves, \\
& & Hawskbay & 15.85 & cloths/towels
\end{tabular}




\begin{tabular}{llll} 
& Sandspit & 8950.78 & bottles of \\
& Paradise & 1750 & water/drinks, \\
& Clifton & 4790 & Cups, Crips/ \\
& Korangi Creek & 780 & sweet packets \\
& Ghizri & 1000 & Straws, toys. \\
5 & Paradise & 70.5 & Food packing \\
& Sandspit & 210 & boxes, \\
& Thermocol /Styrofoam & 200 & Styrofoam from \\
& Related waste & & Ships, cups, \\
& & 430 & Beverages \\
& Glifton & 180 & bottles, metal \\
& & 450 & cans, Lids, \\
& Clifton & 1560 & Batteries \\
\hline
\end{tabular}

\section{Conclusion}

This study demonstrates the baseline data for the distribution and composition of debris along the coast of Karachi, Pakistan by using quadrates method. However in terms of solid waste pollution these beaches of Karachi are moderately polluted as compare to the other beaches of world. This study reveals the human behavior is the key component of solid waste debris on the coastal sides. Therefore public awareness programs and their positive attitude towards reducing the pollution will be helpful to keep the beaches clean.

\section{Acknowledgement}

We would like to thanks all the staff member of Environmental studies department and the under graduate students for their help throughout the studies. Funding resources provided by Institute of Environmental studies, University of Karachi.

\section{Reference}

1. Amaral-Zettler LA, Zettler ER, Slikas B, Boyd GD, Melvin DW, Morrall CE, 5 Proskurowski, G., and Mincer, T.J. The biogeography of the Plastisphere: 6 implications for policy. Front. Ecol. Environ. 2015; 13, 541-546

2. Barnes DKA, Galgani $F$, Thompson RC, \& Barlaz M. Accumulation and fragmentation of plastic debris in global environments. Philosophical Transactions of the Royal Society Series B. 2009; 364:1985-1998.

3. Browne MA, Dissanayake A, Galloway TS, Lowe DM. Ingested microscopic plastic translocates to the circulatory system of the mussel, Mytilus edulis. Environmental Science and Technology. 2008; 42: 5026-5031.

4. Cadee GC. Seabirds and floating plastic debris. Mar. Pollut. Bull. 2002; 44: 1294-1295.

5. Christine AR, seba BS, Klavitter J. Baseline for beached marine debris on sand Island, Midway Atoll, Marine pollution Bulletin. 2012; 64: 1726-1729

6. Clark RB. Marine Pollution. 2008; 237 pp., $5^{\text {th }}$ edition, Oxford University Press, Oxford, UK.

7. Cole M, Webb H, Lindeque PK, Fileman ES, Halsband C, Galloway TS. Isolation of microplastics in biota-rich seawater samples and marine organisms. Scientific Reports. 2014; 4: 1 -8.

8. Engler RE. The complex Interaction between marine debris and toxic chemicals in the Ocean. Environmental Science and Technology. 2012; 46: 12302-12315.

9. Fujieda S, Sasaki K. Stranded debris of foamed plastics on the coast of Eta Island and Kurahashi Island in Hiroshima Bay. Nippon Suisan Gakkaishi. 2005; 71: 755-761 
10. Galgani F, Leaute JP, Moguedet $P$, Souplet A, Verin $Y$, Carpentier A, et al., Litter on the sea floor along European coasts. Marine Pollution Bulletin. 2000; 40: 516-527.

11. Galgani F, Souplet A, Cadiou Y. Accumulation of debris on the deep sea floor off the French Mediterranean coast. Marine Ecology Progress Series. 1996; 142: 225-234.

12. Galil BS, Golik A,Türkay M. Litter at the bottom of the sea: A sea bed survey in the eastern Mediterranean. Marine Pollution Bulletin. 1995; 30: 22-24.

13. Gregory MR. Environmental implications of plastic debris in marine settings e entanglement, ingestion, smothering, hangers-on, hitch-hiking and alien invasions. Philosophical transactions of the royal society of Iondon b: Biological sciences. 2009; 364:1526.

14. Harrison JP, Sapp M, Schratzberger M, Osborn AM. Interactions 124 between microorganisms and marine microplastics: A call for research. Mar. Technol. 125 Soc. J. 2011; 45: 12-20.

15. Heo NW, Hong SH, Han GM, Hong S, Lee J, Song YK, Jang M, Shim WJ. Distribution of small plastic debris in cross-section and high strandline on Heungnam Beach, South Korea. Ocean Sci. J. 2013; 48: 225-233.

16. Hinojosa IA, Thiel M. Foating marine debris in fjords, gulfs and channels of southern Chile. Mar. Pollut. Bull. 2009; 58: 341-350.

17. Jilani S, Status of Metal Pollution in the River and Coastal Areas of Karachi, Middle-East Journal of Scientific Research. 2014; 22 (9): 1288-1293.

18. Jongmyoung Lee, Sunwook Hong, Young Kyung Song, Sang Hee Hong, Yong Chang Jang, Mi Jang, Nak Won Heo, Gi Myung Han, Mi Jeong Lee, Daeseok Kang, Won Joon Shim. Relationships among the abundances of plastic debris in different size classes on beaches in South Korea, Marine Pollution Bulletin. 2013; 77: 349-354

19. Kusui T, M Noda. International survey on the distribution of stranded and buried litter on beaches along the Sea of Japan. Mar. Pollut. Bull. 2003; 47: 175-179.

20. Laist DW. Impacts of marine debris: entanglement of marine life in marine debris including a comprehensive list of species with entanglement and ingestion records. In J.M. Coe and D.B. Rogers (eds) Marine Debris. New York, NY: Springer. 1997; pp. 99-139

21. Lattin GL, Moore CJ, Zellers AF, Moore SL, Weisberg SB. A comparison of neustonic plastic and zooplankton at different depths near the southern California shore. Marine Pollution Bulletin. 2004; 49: 291-294.

22. Merrell TR Jr. Accumulation of plastic litter on beaches of Amchitka Island, Alaska. Mar. Environ. Res. 1980; 3: 171-184.

23. Neelam A, Omm-e-Hany and Shagufta Ishteyaque Microplastic: A potential threat to marine vertebrates "A Mini Review", Journal of Basic and Environmental Sciences. 2018; 5: 155-16.

24. Pham CK, Ramirez-Llodra E, Alt CHS, Amaro $\mathrm{T}$, Bergmann $\mathrm{M}$, Canals $\mathrm{M}$, et al., Marine litter distribution and density in European Seas, from the shelves to deep basins. PLoS ONE. 2014; 9 : e95839.

25. Qari R, Shaffat M. Distribution and abundance of Marine Debris Along the coast of Karachi (Arabian Sea),Pakistan, Pak. J. Sci. ind. res. B. 2015; boil.sci 58 (2) 98-103.

26. Quraishee GS. Influence of the Indus River on the marine environment. In: International Conference on the Management of the Environment. Pak. Aca. Sci. Islamabad. 1985;11: 1-1 12.

27. Ribes LM, Gotzon Basterretxea, Palmar M, Tintore J. Origin and abundance of beach debris in the Balearic Islands, SCIENTIA MARINA. 2007; 71(2): 305-314.

28. Ryan PG, Moore CJ, van Franeker JA, Moloney CL. Monitoring the abundance of plastic debris in the marine environment. Philosophical Transactions of the Royal Society B: Biological Sciences, 2009; 364: 1999-2012

29. Shaheen A, Hina saeed Baig and Shanan Urooj Kazmi. Microbial flora isolated from polluted and non-polluted coastal waters of Karachi, Pak. J. Bot. 2016; 48(4): 1703-1708.

30. Sheavly SB, Register KM. Marine debris \& plastics: environmental concerns, sources, impacts and solutions. J. Polym. Environ. 
2007; 15: 301-305.

31. Thompson RC, Moore CJ, Vom Saal FS, Swan SH. Plastics, the environment and human health: current consensus and future trends. Philosophical Transactions of the Royal Society B: Biological Sciences. 2009; 364: 2153-2166.

32. Zalasiewicz ${ }^{a}$ J, Colin N. Waters Juliana A.Ivar do Sul Patricia L. Corcoran Anthony D.Barnosky Alejandro Cearreta,Agnieszka ${ }^{\mathrm{h}}$ ałuszkahCatherineJeandeliReinholdLeinfeld
erjJ.R.McNeillkWillSteffenIColinSummerhaye s MichaelWagreich MarkWilliamsaAlexander P.WolfeoYasminYonan. The geological cycle of plastics and their use as a stratigraphic indicator of the Anthropocene,Anthropocene. 2016; 13: 4-17

33. Zettler ER, Mincer TJ, Amaral-Zettler, LA. Life in the "Plastisphere": 345 Microbial communities on plastic marine debris. Environ. Sci. Technol. 2013; 47: 7137-7146. 